\title{
Treatment of porcine malignant hyper- thermia: lactate gradient from muscle to blood
}

Gerald A. Gronert MD, C.P. Ahern DVM PHD, James H. Milde

Treatment of $M H$ was studied in 21 pigs, using an isolated perfused caudal body preparation $(L$, transection). Halothane one per cent triggered $M H$; data included oxygen consumption, bloodimuscle lactate levels, plasma potassium, acid-base balance. Three treatment protocols had two phases each: $A-1$, discontinue halothane, inject dantrolene $7.5 \mathrm{mg} \mathrm{kg}^{-1} ; \mathrm{A}-2$, inject $\mathrm{HCO}_{3}^{-}(113 \pm 6 \mathrm{mEq})$. $B-1$, Discontinue halothane, inject $\mathrm{HCO}_{3}^{-}(118 \pm 13$ $m E q) ; B-2$, inject dantrolene $7.5 \mathrm{mg} \cdot \mathrm{kg}^{-1}$. C-1, Continue halothane, inject dantrolene $7.5 \mathrm{mg} \cdot \mathrm{kg}^{-1} ; \mathrm{C}-2$, discontinue halothane, inject $\mathrm{HCO}_{3}^{-}(101 \pm 8 \mathrm{mEq})$.

Dantrolene and $\mathrm{HCO}_{3}^{-}$acted separately and differensly: dantrolene reversed the hypermetabolism, both aerobic and anerobic, and $\mathrm{HCO}_{3}^{-}$reversed the extracellular metabolic acidosis. Semitendinosus muscle biopsies demonstrated that both red and white muscle are involved in $\mathrm{MH}$, that muscle lactate (to $35 \mathrm{\mu mol} \cdot \mathrm{g}^{-1}$ ) consistently exceeded blood lactate (so $22 \mu \mathrm{mol} \cdot \mathrm{ml}^{-1}$ ), and that blood lactate levels were slow to diminish following treatment. One could expect continued release of muscle lactate into blood, despite adequate therapy of $\mathrm{MH}$; this might suggest a recurrence even when such is not the case.

\section{Key words}

MALIGNANT HYPERTHERMIA: muscle energy stores, blood lactate, muscle lactate, dantrolene.

From the Department of Anesthesiology, Mayo Clinic, Rochester, Minnesota and the Department of Veterinary Physiology and Biochemistry, University College of Dublin, Dublin, Ireland.

Address correspondence to: Dr. Gronert, Department of Anesthesiology, University of California, Davis, TB 170, Davis Califomia, 95616.

Supported in part by GM 21729, National Institutes of Health, U.S. Public Health Service.

Dr. Ahern was supported in part by a Wellcome Trust Travel Grant.
The goal of this study was to compare and contrast the specific effects of dantrolene and bicarbonate upon acute episodes of malignant hyperthermia (MH). An isolated perfused preparation provided a situation in which sympathetic function was absent, and in which neither hypotension nor low cardiac output could occur, thereby obviating some factors that can complicate evaluation of results.

\section{Methods}

Twenty-one purebred Pietrain pigs, cared for according to institutional animal care guidelines, weighed $21.6 \pm 1.1 \mathrm{~kg}$. The were identified as susceptible to malignant hyperthermia by the development of hind limb rigidity within three min while manually restrained and breathing three per cent halothane from a close fitting mask, ${ }^{\perp}$ using a non-rebreathing system with a flow rate of eight litres oxygen per minute through a temperature compensated vaporizer.

On the day of study the pigs were anaesthetized with intravenous thiopentone, $15-20 \mathrm{mg} \cdot \mathrm{kg}^{-1}$, and tracheal intubation was performed; a four per cent lidocaine spray prevented laryngospasm during laryngoscopy. The animals were mechanically ventilated with a $5-7 \mathrm{~L} \cdot \mathrm{min}^{-1}$ mixture of nitrous oxide 65 per cent and oxygen 35 per cent, with supplemental thiopentone given as needed. Corporal transection was performed at the level of the first lumbar vertebra. ${ }^{2}$ The aorta and inferior vena cava were cannulated and perfused by a roller pump oxygenator-heat exchanger at flow rates sufficient to provide a mixed venous $\mathrm{PO}_{2}$ greater than $6.7 \mathrm{kPa}$ (50 $\mathrm{mmHg}$ ), for sufficient excess blood flow to allow for subsequent increases in aerobic metabolism. The cephalad portion was exsanguinated to provide additional perfusate volume. These caudal 
preparations were subjected to various drugs, e.g., diazepam, propranolol, ketamine. pentobarbitone and pancuronium, and, over a 10-45 min period, triggered into a malignant hyperthermia response with halothane one per cent. (Evaluation of the responses of individual preparations suggested that the various drugs had not altered the response to therapy.) Once the study was finished in regard to drug evaluation (no more than $70 \mathrm{~min}$ ), the following three protocols were initiated.

The protocols each had three 20 min periods of observation and the measurements occurred at the end of each of the periods. The periods included before treatment, initial treatment, and $20 \mathrm{~min}$ later, the second treatment. The first treatment protocol, $\mathrm{A},(\mathrm{n}=6)$ included $\mathrm{Al}$, discontinuation of halothane plus intravenous dantrolene $7.5 \mathrm{mg} \cdot \mathrm{kg}^{-1}$, and $\mathrm{A} 2$, administration of intravenous $\mathrm{HCO}_{3}^{-}$in a dose sufficient to reverse the base deficit. The second treatment protocol, $\mathrm{B}(\mathrm{n}=6)$ included $\mathrm{B} 1$, discontinuation of halothane plus sufficient $\mathrm{HCO}_{3}^{-}$ to reverse the base deficit, and $B 2$, dantrolene $7.5 \mathrm{mg} \cdot \mathrm{kg}^{-1}$. The third treatment protocol, $\mathrm{C}(\mathrm{n}=$ 9) included $\mathrm{C} 1$, continuation of halothane plus dantrolene $7.5 \mathrm{mg} \cdot \mathrm{kg}^{-1} ; \mathrm{C} 2$, discontinuation of halothane plus $\mathrm{HCO}_{3}^{-}$sufficient to reverse the base deficit.

At the end of each phase - before treatment, initial treatment, and second treatment - muscle biopsies were excised from the predominantly red and the predominantly white portions of the semitendinosus muscle, ${ }^{3}$ providing information relating muscle metabolites to blood lactate and muscle metabolism. Dantrolene and $\mathrm{HCO}_{3}^{-}$were injected into the reservoir for the perfusion pump, dantrolene as a single bolus and $\mathrm{HCO}_{3}^{-}$as bolus doses over 5-10 min, until the desired acid-base response was achieved.

Metabolic values were presumed to represent metabolism of muscle in the caudal preparation; the ratio of caudal muscle to total caudal weight (following transection) is $0.49 .^{2}$ Preparation blood flow and arterial and mixed venous oxygen contents provided data in triplicate for the calculation of preparation oxygen consumption $\left(\mathrm{VO}_{2}\right)$ using the Fick formula. Blood gases and $\mathrm{pH}$ were determined on an electrode-metre at $37^{\circ} \mathrm{C}$ and are uncorrected. An IL Co-oximeter 282 calibrated for pig blood yielded haemoglobin and oxyhaemoglobin values. $\mathrm{O}_{2}$ content was calculated from values for haemo- globin, saturation and $\mathrm{PO}_{2}$. Other measurements or calculations include: base excess (BE), blood lactate, muscle lactate, muscle ATP and phosphocreatine, and plasma potassium (flame photometer). Muscle lactate was analyzed by a modification of the technique for brain lactate. ${ }^{4}$ Muscle ATP and phosphocreatine were extracted by a technique modified from that of Folbergrova et $a l^{5}$ and analyzed according to Lowry and Passonneau. ${ }^{4}$

Data are reported as mean \pm standard error; analysis of variance was used to detect differences between pretreatment and posttreatment values (both phases); any differences were compared by Student's $t$ test for paired values, $p<0.05$ considered significant.

\section{Results}

Similar to the findings of earlier classic papers, ${ }^{6}$ the diagnosis of $\mathrm{MH}$ in these preparations was established by the increase in $\mathrm{VO}_{2}$, lactate and potassium and by the mixed acidosis (Tables I-III). Duration of $\mathrm{MH}$, i.e., the period of increased aerobic and anerobic metabolism prior to commencement of therapy was $35.0 \pm 2.7 \mathrm{~min}$ (treatment A), $44.4 \pm$ 9.9 min (treatment B), $37.3 \pm 2.9$ min (treatment C) and $38.4 \pm 2.8 \mathrm{~min}$ (pooled).

For treatment A, when Al, halothane was discontinued and dantrolene was given, oxygen consumption decreased to near normal levels and mixed venous $\mathrm{PO}_{2}$ increased (Table I). This increase was marked, to $9.6 \mathrm{kPa}(72 \mathrm{mmHg}$ ), and was associated with near normal venous saturation. The acidosis worsened during initial treatment because of the continued release of lactate into the blood, due to the considerable gradient between muscle and blood lactate levels. Potassium did not decrease. After $\mathrm{A} 2, \mathrm{HCO}_{3}^{-}(113 \pm 6 \mathrm{mEq})$, acidosis was now reversed and $\mathrm{PvO}_{2}$ retumed to normal levels; arterial and mixed venous $\mathrm{PCO}_{2}$ levels remained elevated, in part because of increased $\mathrm{CO}_{2}$ production due to buffering of lactate by $\mathrm{HCO}_{3}^{-}$.

For treatment B, when B 1, halothane was discontinued and $\mathrm{HCO}_{3}^{-}$, was used to reverse acidosis (118 $\pm 13 \mathrm{mEq}$ ) but B2, dantrolene was delayed 20 min, $\mathrm{VO}_{2}$ remained elevated until dantrolene was given (Table II). Arterial and mixed venous $\mathrm{PCO}_{2}$ increased with initial treatment (B1), due to continued increased metabolism and buffering of acid by $\mathrm{HCO}_{3}^{-}(118 \pm 13 \mathrm{mEq})$. The $\mathrm{pH}$ was partly 
TABLE 1 Treatment of MH: Group A: halothane off plus dantrolene, $7.5 \mathrm{mg} \cdot \mathrm{kg}^{-1}$; delayed $\mathrm{HCO}_{3}^{-}$, $113 \pm 6 \mathrm{mEq}$; mean $\pm \mathrm{SE}$

\begin{tabular}{|c|c|c|c|c|}
\hline & Units & $\begin{array}{l}\text { Before } \\
\text { treatmeni }\end{array}$ & $\begin{array}{l}\text { Halo off: } \\
\text { Al: } \\
\text { dantrolene }\end{array}$ & $\begin{array}{l}\text { A2: delayed } \\
\mathrm{HCO}_{3}^{-}\end{array}$ \\
\hline$\dot{\mathrm{VO}}_{2}$ & $\mathrm{ml} \cdot \mathrm{min}^{-1} \cdot \mathrm{kg}^{-1}$ & $23.5 \pm 2.5$ & $9.5 \pm 0.4^{*}$ & $8.1=0.3^{*}$ \\
\hline Blood How & $\mathrm{ml} \cdot \mathrm{min}^{-1} \cdot \mathrm{kg}^{-1}$ & $196 \pm 15$ & $197 \pm 14$ & $196 \pm 15$ \\
\hline $\mathrm{PaCO}_{2}$ & $\mathrm{kPa}(\mathrm{mmHg})$ & $\begin{array}{l}7.9 \pm 0.5 \\
(59 \pm 4)\end{array}$ & $\begin{array}{l}6.5 \pm 0.1^{*} \\
\left(49 \pm 1^{*}\right)\end{array}$ & $\begin{array}{l}6.9 \pm 0.3 \\
(52 \pm 2)\end{array}$ \\
\hline $\mathrm{P} \mathrm{CO}_{2}$ & $\mathrm{kPa}(\mathrm{mmHg})$ & $\begin{array}{l}14.3 \pm 1.3 \\
(107 \pm 10)\end{array}$ & $\begin{array}{l}9.7 \pm 0.3^{*} \\
\left(73 \pm 2^{*}\right)\end{array}$ & $\begin{array}{l}9.2 \pm 0.4^{*} \\
\left(69 \pm 3^{*}\right)\end{array}$ \\
\hline $\mathrm{pHa}$ & & $7.01 \pm 0.05$ & $6.90 \pm 0.03$ & $7.45 \pm 0.03 *$ \\
\hline BEa & $\mathrm{mEq} \cdot \mathrm{L}^{-1}$ & $-16 \pm 2$ & $-22 \pm 1$ & $+2 \pm 2^{*}$ \\
\hline Lactate, a & $\mu \mathrm{mol} \cdot \mathrm{ml}^{-1}$ & $14.7 \pm 2.3$ & $18.0 \pm 2.5$ & $18.1 \pm 3.1$ \\
\hline White m & $\mu \mathrm{mol} \cdot \mathrm{g}^{-1}$ & $22.9 \pm 4.0$ & $27.0 \pm 3.4$ & $28.5 \pm 3.9$ \\
\hline Red m & $\mu \mathrm{mol} \cdot \mathrm{g}^{-1}$ & $35.3 \pm 4.5$ & $35.1 \pm 4.7$ & $22.5 \pm 4.4$ \\
\hline $\mathrm{PaO}_{2}$ & $\mathrm{kPa}(\mathrm{mmHg})$ & $\begin{array}{l}18.9 \pm 2.7 \\
(142 \pm 20)\end{array}$ & $\begin{array}{l}35.7 \pm 5.5 \\
(268 \pm 41)\end{array}$ & $\begin{array}{l}31.5 \pm 1.5 \\
(236 \pm 11)\end{array}$ \\
\hline $\mathrm{Pry}_{2}$ & $\mathrm{kPa}(\mathrm{mmHg})$ & $\begin{array}{l}4.8 \pm 0.5 \\
(36 \pm 4)\end{array}$ & $\begin{array}{l}9.6 \pm 0.5^{*} \\
\left(72 \pm 4^{*}\right)\end{array}$ & $\begin{array}{l}6.4 \pm 0.3^{*} \\
\left(48 \pm 2^{*}\right)\end{array}$ \\
\hline $\mathrm{K}^{+} \mathbf{a}$ & $\mathrm{mEq} \cdot \mathrm{L}^{-1}$ & $6.3 \pm 0.5$ & $7.1 \pm 0.6$ & $7.2 \pm 0.7$ \\
\hline
\end{tabular}

*Different from "before treatment," $p<0.05$.

TABLE II Treatment of MH: Group B: halothane off plus $\mathrm{HCO}_{3}^{-}, 118 \pm 13 \mathrm{mEq}$; delayed dantrolene, $7.5 \mathrm{mg} \cdot \mathrm{kg}^{-1}$; mean $\pm \mathrm{SE}$

\begin{tabular}{|c|c|c|c|c|}
\hline & Units & $\begin{array}{l}\text { Before } \\
\text { treatment }\end{array}$ & $\begin{array}{l}\mathrm{Bl}: \\
\text { halo off, } \\
\mathrm{HCO}_{3}^{-}\end{array}$ & $\begin{array}{l}\text { B2: delayed } \\
\text { danrrolene }\end{array}$ \\
\hline $\mathrm{VO}_{2}$ & $\mathrm{ml} \cdot \mathrm{min}^{-1} \cdot \mathrm{kg}^{-1}$ & $14.7 \pm 1.9$ & $12.5 \pm 1.5$ & $7.5 \pm 0.4^{*}$ \\
\hline Blood flow & $\mathrm{ml} \cdot \min { }^{-1} \cdot \mathrm{kg}^{-1}$ & $178 \pm 15$ & $177 \pm 15$ & $177 \pm 15$ \\
\hline $\mathrm{PaCO}_{2}$ & $\mathrm{kPa}(\mathrm{mmHg})$ & $\begin{array}{l}6.7 \pm 0.3 \\
(50 \pm 2)\end{array}$ & $\begin{array}{l}8.5 \pm 0.5^{*} \\
\left(64 \pm 4^{*}\right)\end{array}$ & $\begin{array}{l}6.8 \pm 0.3 \\
(51 \pm 2)\end{array}$ \\
\hline $\mathrm{P}_{\bar{V}} \mathrm{CO}_{2}$ & $\mathrm{kPa}(\mathrm{mmHg})$ & $\begin{array}{c}10.4 \pm 0.8 \\
(78 \pm 6)\end{array}$ & $\begin{array}{l}14.5 \pm 1.2^{*} \\
\left(109 \pm 9^{*}\right)\end{array}$ & $\begin{array}{l}9.5 \pm 0.5 \\
(71 \pm 4)\end{array}$ \\
\hline $\mathrm{pHa}$ & & $7.16 \pm 0.05$ & $7.27 \pm 0.02$ & $7.32 \pm 0.02 *$ \\
\hline $\mathrm{BEa}$ & $\mathrm{mEq} \cdot \mathrm{L}^{-1}$ & $-9 \pm 2$ & $+3 \pm 2^{*}$ & $+1 \pm 1 *$ \\
\hline Lactate, a & $\mu \mathrm{mol} \cdot \mathrm{ml}^{-1}$ & $10.2 \pm 2.7$ & $22.0 \pm 2.2^{*}$ & $21.6 \pm 3.1^{*}$ \\
\hline White m & $\mu \mathrm{mol} \cdot \mathrm{g}^{-1}$ & $22.8 \pm 3.0$ & $29.0 \pm 3.4$ & $33.3 \pm 4.2$ \\
\hline Red $m$ & $\mu \mathrm{mol} \cdot \mathrm{g}^{-1}$ & $22.1 \pm 3.5$ & $35.9 \pm 2.2$ & $34.0 \pm 4.5$ \\
\hline $\mathrm{PaO}_{2}$ & $\mathrm{kPa}(\mathrm{mmHg})$ & $\begin{array}{l}23.2 \pm 1.6 \\
(174 \pm 12)\end{array}$ & $\begin{array}{l}21.6 \pm 2.1 \\
(162 \pm 16)\end{array}$ & $\begin{array}{l}28.7 \pm 2.1 \\
(215 \pm 16)\end{array}$ \\
\hline $\mathrm{PṼO}_{2}$ & $\mathrm{kPa}(\mathrm{mmHg})$ & $\begin{array}{l}5.5 \pm 0.4 \\
(41 \pm 3)\end{array}$ & $\begin{array}{l}5.5 \pm 0.4 \\
(41 \pm 3)\end{array}$ & $\begin{array}{l}6.5 \pm 0.3^{*} \\
\left(49 \pm 2^{*}\right)\end{array}$ \\
\hline $\mathrm{K}^{+} \mathrm{a}$ & $\mathrm{mEq} \cdot \mathrm{L}^{-1}$ & $5.8 \pm 0.3$ & $5.9 \pm 0.2$ & $6.2 \pm 0.3$ \\
\hline
\end{tabular}

*Different from "before treatment," $p<0.05$.

corrected toward normal and base excess was completely corrected. There was again a gradient between muscle and blood lactate, and blood lactate continued to increase during the first phase of treatment, presumably because of the gradient and the continued elevated metabolism due to delayed treatment by dantrolene. Potassium again was essentially unchanged.

For treatment $\mathrm{C}$, where $\mathrm{Cl}$, halothane was continued and dantrolene was administered, and $\mathrm{C} 2$, halothane was discontinued and $\mathrm{HCO}_{3}^{-}$given (101 $\pm 8 \mathrm{mEq}$ ) (Table III): $\mathrm{VO}_{2}$ decreased with the 
TABLE III Treatment of MH: Group C: halothane continued plus dantrolene, $7.5 \mathrm{mg} \cdot \mathrm{kg}^{-1}$; delayed $\mathrm{HCO}_{3}^{-}, 101 \pm 8 \mathrm{mEq}$; and halothane off, mean $\pm \mathrm{SE}$

\begin{tabular}{|c|c|c|c|c|}
\hline & Units & $\begin{array}{l}\text { Before } \\
\text { treatment }\end{array}$ & $\begin{array}{l}\mathrm{Cl}: \\
\text { halo cont, } \\
\text { dantrolene }\end{array}$ & $\begin{array}{l}\mathrm{C2:} \text { halo off, } \\
\mathrm{HCO}_{3}^{-}\end{array}$ \\
\hline$\dot{\mathrm{V}} \mathrm{O}_{2}$ & $\mathrm{ml} \cdot \mathrm{min}^{-1} \cdot \mathrm{kg}^{-1}$ & $22.0 \pm 1.4$ & $7.7 \pm 0.4^{*}$ & $7.7 \pm 0.5^{*}$ \\
\hline Blood flow & $\mathrm{ml} \cdot \mathrm{min}^{-1} \cdot \mathrm{kg}^{-1}$ & $213 \pm 12$ & $212 \pm 12$ & $209 \pm 13$ \\
\hline $\mathrm{PaCO}_{2}$ & $\mathrm{kPa}(\mathrm{mmHg})$ & $\begin{array}{l}7.2 \pm 0.3 \\
(54 \pm 2)\end{array}$ & $\begin{array}{l}6.0 \pm 0.1^{*} \\
\left(45 \pm 1^{*}\right)\end{array}$ & $\begin{array}{l}6.1 \pm 0.3^{*} \\
\left(46 \pm 2^{*}\right)\end{array}$ \\
\hline $\mathrm{P}^{\mathrm{v} C \mathrm{CO}_{2}}$ & $\mathrm{kPa}(\mathrm{mmHg})$ & $\begin{array}{c}12.8 \pm 0.8 \\
(96 \pm 6)\end{array}$ & $\begin{array}{l}8.3 \pm 0.3^{*} \\
\left(62 \pm 2^{*}\right)\end{array}$ & $\begin{array}{l}7.8 \pm 0.4^{*} \\
\left(59 \pm 3^{*}\right)\end{array}$ \\
\hline $\mathrm{pHa}$ & & $6.96 \pm 0.05$ & $6.91 \pm 0.05$ & $7.37 \pm 0.03^{*}$ \\
\hline $\mathrm{BEa}$ & $\mathrm{mEq} \cdot \mathrm{L}^{-1}$ & $-19 \pm 2$ & $-22=2$ & $+2 \pm 2^{*}$ \\
\hline Lactate, a & $\mu \mathrm{mol} \cdot \mathrm{ml}^{-1}$ & $14.9 \pm 1.6$ & $15.8 \pm 2.1$ & $16.8 \pm 1.9$ \\
\hline White $\mathrm{m}$ & $\mu \mathrm{mol} \cdot \mathrm{g}^{-1}$ & $33.3 \pm 4.0$ & $35.5 \pm 5.0$ & $29.2 \pm 3.9$ \\
\hline Red $m$ & $\mu \mathrm{mol} \cdot \mathrm{g}^{-1}$ & $34.7 \pm 1.8$ & $30.8 \pm 4.3$ & $31.5 \pm 3.4$ \\
\hline $\mathrm{PaO}_{2}$ & $\mathrm{kPa}(\mathrm{mmHg})$ & $\begin{array}{l}31.1 \pm 2.8 \\
(233 \pm 21)\end{array}$ & $\begin{array}{l}33.2 \pm 0.9 \\
(249 \pm 7)\end{array}$ & $\begin{array}{l}31.9 \pm 0.7 \\
(239 \pm 5)\end{array}$ \\
\hline $\mathrm{PỹO}_{2}$ & $\mathrm{kPa}(\mathrm{mmHg})$ & $\begin{array}{l}5.9 \pm 0.5 \\
(44 \pm 4)\end{array}$ & $\begin{array}{c}10.5 \pm 0.5^{*} \\
\left(79 \pm 4^{*}\right)\end{array}$ & $\begin{array}{l}68 \pm 0.3 \\
(51 \pm 2)\end{array}$ \\
\hline $\mathrm{K}^{+} \mathrm{a}$ & $\mathrm{mEq} \cdot \mathrm{L}^{-1}$ & $6.6 \pm 0.4$ & $7.6 \pm 0.3$ & $7.2 \pm 0.3$ \\
\hline
\end{tabular}

*Different from "before treatment," $\mathrm{p}<0.05$.

administration of dantrolene, despite the continuation of halothane. Arterial and mixed venous $\mathrm{CO}_{2}$ decreased as a result, but arterial $\mathrm{pH}$ and base excess were essentially unchanged until bicarbonate (101 $\pm 8 \mathrm{mEq})$ was given to reverse the metabolic acidosis. Blood lactate was essentially unchanged through both treatment phases and there was again a gradient between muscle and blood lactate levels. Mixed venous $\mathrm{PO}_{2}$ increase dramatically with the administration of dantrolene; the higher $\mathrm{PvO}_{2}$ was associated with essentially normal oxygen saturation. Mixed venous $\mathrm{PO}_{2}$ then decreased following $\mathrm{HCO}_{3}^{-}$and approached expected normal values (at these flow rates). Again, plasma potassium levels were essentially unchanged regardless of treatment (in this preparation).

Blood pressure was well maintained; temperature ranged from 37.0 to $37.8^{\circ} \mathrm{C}$ in all preparations, the lack of marked rise being due to the relative cooling effect by the heat exchanger maintained at $37^{\circ} \mathrm{C}^{2}$ Muscle energy stores are presented in Table IV, and statistical data in Table $\mathrm{V}$.

\section{Discussion}

The results confirm the separate and different actions of dantrolene and $\mathrm{HCO}_{3}^{-}$upon the biochemical-acid-base picture of malignant hyperthermia. The effects of their combined use in vivo are shown to be due to disparate actions, unlikely to interact with one another. $1,7,8$ Dantrolene acts intracellularly to halt the metabolic furnace within the myofibrils, thus stopping the production of metabolic $\mathrm{CO}_{2}$ and lactate. ${ }^{1,7,8}$ Furthermore, with adequate perfusion, it is effective even $30-50 \mathrm{~min}$ after $\mathrm{MH}$ has developed. $\mathrm{HCO}_{3}^{-}$reverses the metabolic acidosis within extracellular fluid, but temporarily adds to the respiratory acidosis through the production of $\mathrm{CO}_{2}$ via neutralization of lactate; it adds to heat production because this neutralization is exothermic.

While initial values for base excess estimate blood lactate, the actual amount of lactate in muscle is considerably greater. This disparity between muscle and blood lactate levels has also been observed in vivo: (1) during cycle exercise in man, the gradient progresses to $10 \mathrm{mmol} \cdot \mathrm{L}^{-1}$ as muscle lactate approaches $18.5 \mathrm{mmol} \cdot \mathrm{kg}^{-1}$ wet weight, presuming that wet weight and tissue water have equivalent metric mass; ${ }^{9}(2)$ during porcine $\mathrm{MH},{ }^{10}$ the gradient matches that observed in the present study, $10-15 \mathrm{mmol} \cdot \mathrm{L}^{-1}$ (Tables I-III); this comparison is approximate, ${ }^{9}$ as the muscle lactate values in the porcine study were expressed per $\mathrm{kg}$ dry weight. ${ }^{10}$ This lactate gradient is probably due to decreased membrane permeability of the lactate anion. With time, lactate does cross from muscle 
TABLE IV Semitendinosus muscle energy stores, mean \pm SE

\begin{tabular}{lllrr}
\hline & \multicolumn{4}{l}{ Treatment A } \\
\cline { 3 - 5 } & & $\begin{array}{l}\text { Before } \\
\text { treasment }\end{array}$ & \multicolumn{1}{l}{ Treatment } & \multicolumn{1}{l}{ Treatment } \\
& & & \multicolumn{1}{l}{$A 2$} \\
\hline ATP & White & $3.6 \pm 0.5$ & $3.4 \pm 0.4$ & $3.5 \pm 0.5$ \\
$\mu \mathrm{mol} \cdot \mathrm{g}^{-1}$ & Red & $2.6 \pm 0.4$ & $2.6 \pm 0.3$ & $3.4 \pm 0.3$ \\
Phosphocreatine & White & $9.1 \pm 2.4$ & $12.9 \pm 1.2$ & $10.5 \pm 1.8$ \\
$\mu \mathrm{mol} \cdot \mathrm{g}^{-1}$ & Red & $5.2 \pm 1.4$ & $8.8 \pm 2.6$ & $16.0 \pm 2.6$ \\
\hline
\end{tabular}

\begin{tabular}{lllll}
\hline & \multicolumn{4}{l}{ Treatment $B$} \\
\cline { 3 - 5 } & & $\begin{array}{l}\text { Before } \\
\text { treatment }\end{array}$ & Treatment & Treatment \\
& & & $B 2$ \\
\hline ATP & White & $3.8 \pm 0.3$ & $3.7 \pm 0.3$ & $3.5 \pm 0.5$ \\
$\mu \mathrm{mol} \cdot \mathrm{g}^{-1}$ & Red & $3.1 \pm 0.6$ & $2.7 \pm 0.3$ & $2.4 \pm 0.3$ \\
Phosphocreatine & White & $8.2 \pm 2.2$ & $5.9 \pm 1.2$ & $8.2 \pm 2.4$ \\
$\mu \mathrm{mol}^{-1} \mathrm{~g}^{-1}$ & Red & $5.7 \pm 1.4$ & $3.2 \pm 0.6$ & $5.1 \pm 1.3$ \\
\hline
\end{tabular}

\begin{tabular}{lllll}
\hline \multicolumn{4}{l}{ Treatment $C$} \\
\cline { 3 - 5 } & & $\begin{array}{l}\text { Before } \\
\text { treatment }\end{array}$ & Treatment & Treatment \\
& & & $C 2$ \\
\hline ATP & White & $3.2 \pm 0.4$ & $2.8 \pm 0.4$ & $3.5 \pm 0.4$ \\
$\mu$ mol $\cdot \mathrm{g}^{-1}$ & Red & $2.5 \pm 0.2$ & $2.5 \pm 0.4$ & $2.3 \pm 0.5$ \\
Phosphocreatine & White & $3.6 \pm 1.3$ & $7.8 \pm 1.6$ & $9.8 \pm 1.9$ \\
$\mu$ mol $\cdot \mathrm{g}^{-1}$ & Red & $2.8 \pm 0.9$ & $7.5 \pm 2.1$ & $7.2 \pm 1.9$ \\
\hline
\end{tabular}

Treatment A: (1) Halothane discontinued plus dantrolene 7.5 $\mathrm{mg} \cdot \mathrm{kg}^{-1}$; (2) delayed $\mathrm{HCO}_{3}^{-}(113 \pm 6 \mathrm{mEq})$.

Treatment B: (1) Halothane discontinued plus $\mathrm{HCO}_{3}^{-}(118 \pm 13$ $\mathrm{mEq}$ ); (2) delayed dantrolene $7.5 \mathrm{mg} \cdot \mathrm{kg}^{-1}$.

Treatment C: (1) Halothane continued plus dantrolene 7.5 $\mathrm{mg} \cdot \mathrm{kg}^{-1}$; (2) halothane discontinued plus $\mathrm{HCO}_{3}^{-}(101 \pm 8 \mathrm{mEq})$ See text for details.

into blood and BE again decreases. This may lead to the clinical interpretation that $\mathrm{MH}$ has been inadequately treated or has recurred. Obviously, the entire picture must be examined; if in doubt as to lactate diffusion vs continued or recurrent $\mathrm{MH}$ episodes, there is little risk in repeating dantrolene. Certainly the recurrent metabolic acidosis (based upon blood acid-base balance) must be satisfactorily treated. In the present study, muscle and blood levels of lactate decreased little if any in the 20 to 40 min period following effective treatment with dantrolene. While this may also in part be due to the
TABLE V Statistics

\begin{tabular}{|c|c|c|c|c|}
\hline \multicolumn{2}{|c|}{ Treatment phase } & \multirow[t]{2}{*}{$F$ value } & \multirow[t]{2}{*}{$T$ value } & \multirow[t]{2}{*}{$p$} \\
\hline \multicolumn{2}{|l|}{ For Table I } & & & \\
\hline \multirow[t]{2}{*}{$\mathrm{VO}_{2}$} & $\mathrm{~A} 1$ & 26.94 & 5.14 & $0.001<\mathrm{p}<0.01$ \\
\hline & A2 & & 6.35 & $0.001<\mathrm{p}<0.01$ \\
\hline $\mathrm{PaCO}_{2}$ & Al & 3.29 & 3.38 & $0.01<p<0.02$ \\
\hline \multirow{2}{*}{$\mathrm{PvCO}_{2}$} & Al & 11.94 & 4.31 & $0.001<p<0.01$ \\
\hline & $\mathrm{A} 2$ & & 4.90 & $0.001<p<0.01$ \\
\hline \multirow[t]{2}{*}{$\mathrm{PVO}_{2}$} & Al & 25.16 & 6.03 & $0.001<\mathrm{p}<0.01$ \\
\hline & A2 & & 2.93 & $0.02<p<0.05$ \\
\hline $\mathrm{pHa}$ & A1 & 58.90 & 15.80 & $\mathrm{p}<0.001$ \\
\hline BEa & $\mathrm{A} 2$ & 90.54 & 18.48 & $\mathrm{p}<0.001$ \\
\hline \multicolumn{5}{|l|}{ For Table II } \\
\hline \multirow{2}{*}{$\begin{array}{l}\mathrm{PaCO}_{2} \\
\mathrm{PuCO}_{2}\end{array}$} & B1 & 8.34 & 6.22 & $0.001<p<0.01$ \\
\hline & B1 & 10.04 & 6.40 & $0.001<p<0.01$ \\
\hline \multirow[t]{2}{*}{$\mathrm{BEa}$} & B1 & 11.97 & 3.21 & $0.02<\mathrm{p}<0.05$ \\
\hline & B2 & & 3.12 & $0.02<p<0.05$ \\
\hline \multirow[t]{2}{*}{ Lactate a } & B1 & 6.18 & 9.53 & $p<0.001$ \\
\hline & B2 & & 8.75 & $p<0.001$ \\
\hline $\mathrm{VO}_{2}$ & B2 & 7.66 & 4.74 & $0.001<p<0.01$ \\
\hline $\mathrm{pHa}$ & B2 & 5.24 & 2.60 & $0.02<p<0.05$ \\
\hline $\mathrm{PvO}_{2}$ & B2 & 2.79 & 3.71 & $0.01<\mathrm{p}<0.02$ \\
\hline \multicolumn{5}{|c|}{ For Table III } \\
\hline \multirow[t]{2}{*}{$\mathrm{VO}_{2}$} & $\mathrm{Cl}$ & 77.30 & 10.40 & $p<0.001$ \\
\hline & $\mathrm{C} 2$ & & 12.79 & $\mathrm{p}<0.001$ \\
\hline \multirow[t]{2}{*}{$\mathrm{PaCO}_{2}$} & $\mathrm{Cl}$ & 6.99 & 5.53 & $\mathrm{p}<0.001$ \\
\hline & $\mathrm{C} 2$ & & 4.59 & $0.001<p<0.01$ \\
\hline $\mathrm{Pv} \mathrm{CO}_{2}$ & $\mathrm{Cl}$ & 22.37 & 6.62 & $\mathrm{p}<0.001$ \\
\hline $\mathrm{PviO}_{2}$ & $\mathrm{Cl}$ & 30.87 & 9.03 & $p<0.001$ \\
\hline $\mathrm{pHa}$ & $\mathrm{C} 2$ & 26.80 & 10.64 & $\mathrm{p}<0.001$ \\
\hline BEa & $\mathrm{C} 2$ & 40.29 & 9.96 & $\mathrm{p}<0.001$ \\
\hline
\end{tabular}

absence of the liver, very high blood lactate levels are slow to return to normal even in intact subjects, as observed in malignant hyperthermia (pigs) ${ }^{\prime}$ or sustained severe excercise (humans). "I

Our study suggests that the increase in metabolism, in association with artifically maintained and elevated preparation blood flows, resulted in a stable situation in which membrane destruction did not apparently occur. These blood flows possibly prevented ischaemia and the associated relatively rapid membrane failure that can occur in the presence of hyper-metabolism at an elevated temperature. It is not possible to predict the duration of this stability, or its relationship to the magnitude of increase in blood flow. Our preparations may have been easier to maintain because temperature changed little; however, the marked acid base and electrolyte abnormalities undoubtedly provided considerable stress, even in this restricted situation. 
In clinical episodes, where control of regional muscle blood flow is indirect, treatment should be delayed as little as possible.

A recent study describing ponies with a biochemical picture of severe fulminant malignant hyperthermia was most unusual, because the four ponies survived without apparent problems, even though the administration of halothane and a succinylcholine infusion was prolonged, and treatment involved only cooling and reversal of acidosis. ${ }^{12}$ This suggests that this species, or this particular herd, may maintain skeletal muscle blood flow more effectively than those in which similar biochemical aberrations are uniformly fatal. Presumably, once cardiac output falls and loss of flow occurs, there is a dramatic increase in tissue permeability resulting in cell breakdown.

In the present study, dantrolene was effective in decreasing metabolism even though the administration of halothane was continued. This does not imply that dantrolene will inhibit the effect of halothane: in the intact pig, halothane eventually overrides the effect of dantrolene and retriggers malignant hyperthermia. ${ }^{1}$

Measurements of muscle metabolites and energy sources indicate that in this situation the muscle, while stressed, had viable amounts of ATP (Table IV), but increased lactate (Tables I-UI), reflecting marked increases in anaerobic metabolism. The muscle data suggest that both red and white muscle are involved in susceptibility to $\mathrm{MH}$. Potassium levels in this situation relate to increased metabolism, associated ionic fluxes, increased cellular permeability and perhaps an exchange of potassium from the cell to the extracellular fluid secondary to the intracellular acidosis. Potassium levels did not decrease with treatment, probably due to the limited volume for redistribution and the absence of hepatic, renal and/or bowel function. Changes in oxygen consumption and lactate production during hypermetabolism were less marked in one group of pigs (Table II, initial values, before treatment). This difference did not alter responses to therapy and appears to be fortuitous.

This study provides a lesson in abnormal physiology, illustrating the need to interpret $\mathrm{PO}_{2}$ in terms of acid-base balance. Note that the mixed venous $\mathrm{PO}_{2}$ 's of $9.6 \mathrm{kPa}$ (72 mmHg) (Table I) and $10.5 \mathrm{kPa}$ ( $79 \mathrm{mmHg}$ ) (Table III) are dramatic overshoots for mixed venous $\mathrm{PO}_{2}$ when metabolism is normal.
These illustrate the pronounced shift to the right of the oxyhaemoglobin dissociation curve with $\mathrm{pH}$ 6.90-6.91; the shift and the elevated $\mathrm{PO}_{2}$ values were reversed following administration of $\mathrm{HCO}_{3}^{-}$. The modest increases in arterial $\mathrm{CO}_{2}$ tension indicate adequate function of the extracorporeal lung in eliminating $\mathrm{CO}_{2}$ at times when mixed venous levels of $\mathrm{PCO}_{2}$ ranged to $14.7 \mathrm{kPa}(110 \mathrm{mmHg})$. This again confirms the finding that mixed venous $\mathrm{CO}_{2}$ levels reflect whole body $\mathrm{CO}_{2}$ stores better than do arterial levels; ${ }^{13}$ additionally the venous minus arterial $\mathrm{CO}_{2}$ difference may provide a useful diagnostic tool. This also explains the usefulness of measurements of end-expired $\mathrm{CO}_{2}$ in diagnosing malignant hyperthermia. ${ }^{14,15}$

These data clearly demonstrate that dantrolene is therapeutically effective in $\mathrm{MH}$ by virtue of its action in decreasing $\mathrm{VO}_{2}$. While we believe that it halts lactate production as well, this action was not as obvious, because lactate crosses membranes slowly, and accumulated muscle lactate continued to affect blood levels for a considerable period of time after muscle lactate production had plateaued (presumably production had stopped). Finally, potassium levels also remained elevated after effective therapy, a situation not usually observed in intact subjects; it appears that the rapid return of serum potassium to normal levels after dantrolene therapy is related more to re-distribution, probable hepatic uptake and renal excretion than to intrafibrillar return of potassium. This latter mechanism of potassium control is apparently ineffective during recovery from acute $\mathrm{MH}$.

What do these three facets suggest about the aetiology of $\mathrm{MH}$ ? Most believe that these changes in $\mathrm{VO}_{2}$, lactate and potassium occur secondary to uncontrolled increases in intracellular free ionized calcium that are related to acutely malfunctioning sarcoplasmic reticulum. However, while increased $\mathrm{VO}_{2}$, lactate and potassium can all be related to these muscle phenomena, only one, $\mathrm{VO}_{2}$, recovered rapidly after dantrolene. $\mathrm{VO}_{2}$ directly reflects mitochondrial metabolism. Some, particularly Cheah and Cheah, would associate these findings with mitochondrial dysfunction, which in turn alters function of the sarcoplasmic reticulum (SR). ${ }^{16}$ They theorize that increased calcium stimulates phospholipase $A_{2}$, which in turn causes the release of free fatty acids from mitochondria, which in tum attenuate SR function and diminish calcium bind- 
ing; Cheah also suggests a role for calmodulin. ${ }^{17}$ While these inter-relationships are generally accepted in regard to muscle physiology, their role in $\mathrm{MH}$ is but partly understood; in addition, it is not at all clear what causes the original increase in calcium that sets the entire system in motion. The Cheahs frequently obtain their mitochondrial and SR organelle material post-mortem. We believe that the trauma of slaughter or death may at times constitute sufficient stress to initiate acute $\mathrm{MH}$ responses in their pig model. If so, their observations may in part reflect secondary stress-induced phenomena rather than primary dysfunction present in the baseline, resting, or untriggered state. This variable could affect the interpretation of their observations. We conclude that the increase in $\mathrm{VO}_{2}$ in this study does not necessarily signify mitochondrial dysfunction. However, the Cheahs' theory is of great interest, and it may yet explain many $\mathrm{MH}$ phenomena. It still does not directly account for initial triggering; the complex inter-related phenomena resulting in these responses may simply reflect an imbalance between energy supply and demand; the mechanisms are decidedly similar to those involved in brain ischaemia and/or hypoxia. ${ }^{18}$

In summary, the keystone of $\mathrm{MH}$ therapy is dantrolene and $\mathrm{HCO}_{3}^{-}$, and their use should be prompt. Measurements of base excess should be interpreted with caution, as they underestimate tissue metabolic acidosis.

\section{References}

1 Gronert GA, Milde JH, Theye RA. Dantrolene in porcine malignant hyperthermia. Anesthesiology 1976; 44: 488-95.

2 Gronert GA, Milde JH, Taylor SR. Porcine muscle responses to carbachol, $\alpha$ and $\beta$-adrenoceptor agonists, halothane or hyperthermia. J Physiol 1980; 307: 319-33.

3 Gallant EM. Histochemical observations on muscle from normal and malignant hyperthermia-susceptible swine. Am J Vet Res 1980; 41: 1069-71.

4 Lowry $O L$, Passonneau $J$. A flexible system of enzymatic analysis. Academic Press, NY, 1972.

5 Folbergrova J, MacMillan V, Siesjö BK. The effect of moderate and marked hypercapnia upon the energy state and upon the cytoplasmic NADH/ $\mathrm{NAD}^{+}$ratio of the rat brain. J Neurochem 1972; 19: 2497-505.
6 Berman MC, Harrison GG, Bull AB, Kench JE. Changes underlying halothane-induced malignant hyperpyrexia in Landrace pigs. Nature 1970; 225 : 653-5.

7 Kolb ME, Horne ML, Martz R. Dantrolene in human malignant hyperthermia; a multicenter study. Anesthesiology 1982; 56: 254-62.

8 Flewellen EH, Nelson TE. Dantrolene dose response in malignant hyperthermia-sysceptible (MHS) swine: method to obtain prophylaxis and therapeusis. Anesthesiology 1980; 52: 303-8.

9 Jacobs IRA, Kaiser $P$. Lactate in blood, mixed skeletal muscle, and FT or ST fibres during cycle exercise in man. Acta Physiol Scand 1982; 114: $461-6$.

10 Hall GM, Lucke JN. Porcine malignant hyperthermia IX: changes in the concentrations of intramuscular high-energy phosphates, glycogen and glycogen intermediates. Br J Anaesth 1983; 55: 635-40.

11 Stamford BA, Moffatt RJ, Weltman A, Maldonaldo $C$, Curtis $M$. Blood lactate disappearance after supramaximal one-legged exercise. J Appl Physiol 1978; 45: 244-8.

12 Hildebrand SV, Howitt GA. Succinylcholine infusion associated with hyperthermia in ponies anesthetized with halothane. Am J Vet Res 1983; 44: 2280-4.

13 Gronert GA, Theye RA. Halothane-induced porcine malignant hyperthermia: metabolic and hemodynamic changes. Anesthesiology 1976; 44: 36-43.

14 Verburg MP, Oerlemans FTJ, van Bennekom CA, Gielen MJM, de Bruyn CHMM, Crul JF. In vivo induced malignant hyperthermia in pigs. I. Physiological and biochemical changes and the influence of dantrolene sodium. 1984; Acta Anaesthesiol Scand 28: $1-8$.

15 Liebenschütz F, Mai C, Pickerodt VMA. Increased carbon dioxide production in two patients with malignant hyperpyrexia and its control by dantrolene. Br J Anaesth 1979; 51: 899-903.

16 Cheah KS, Cheah AM. Skeletal muscle mitochondrial phospholipase $A_{2}$ and the interaction of mitochondria and sarcoplasmic reticulum in porcine malignant hyperthermia. Biochim et Biophys Acta 1981; 638: 40-9.

17 Cheah $K S$. Skeletal-muscle mitochondria and phospholipase $A_{2}$ in malignant hyperthermia. Biochem Soc Trans 1984; 12: 358-60.

18 Siesjö BK. Cerebral circulation and metabolism. J Neurosurg 1984; 60: 883-908. 
Résumé

Le traitement de l'hyperthermie maligne a été étudié chez 21 cochons, utilisant une préparation de perfusion caudale isolée (transection L1). Un pour cent d'halothane a déclenché l'hyperthermie maligne; les données recueillies inclus la consommation d'oxygène, le niveau de lactate dans le sangimuscle, le potassium sérique et la balance acido-basique. Trois protocales de traitement avaient chacun deux phases: A-1) l'arrêt de l' halothane, l'injection de dantrolène $7.5 \mathrm{mg} \cdot \mathrm{kg}^{-1}$; A-2) l' injection de $\left.\mathrm{HCO}_{3}^{-}(113 \pm 6 \mathrm{mEq}) . \mathrm{B}-1\right)$ l'arrêt de l'halothane, l'injection de l'HCO$-(118 \pm 13 \mathrm{mEq}) ; B-2)$ l'injection de dantrolene $7.5 \mathrm{mg} \cdot \mathrm{kg}^{-1}$. C-1) continue ('halothane, l'injection de dantrolène $\left.7.5 \mathrm{mg} \cdot \mathrm{kg}^{-1} ; \mathrm{C}-2\right)$ a cessé l' halothane, l' injection de $\mathrm{HCO}_{3}^{-}(101 \pm 8 \mathrm{mEq})$.

Le dantrolène et le $\mathrm{HCO}_{3}^{-}$ont agi séparément et différemment: le dantrolène a renversé l' hypermétabolisme, tant aérobique qu'anérobique, et le $\mathrm{HCO}_{3}^{-}$a renversé l'acidose métabolique extracellulaire. Les biopsies du muscle ont démontré que les deux groupes de muscles rouge et blanc sont impliqués dans l'hyperthermie maligne, que le lactate des muscles $\left(35 \mu \mathrm{mol} \cdot \mathrm{g}^{-i}\right)$ était constamment plus élevé que lactate sérique $\left(22 \mu \mathrm{mol} \cdot \mathrm{ml}^{-1}\right)$. et que les niveaux sériques de lactate tardaient à diminuer après traitement. On pourrait s'attendre à une libération continue du lactate musculaire dans le sang, malgré une thérapie adéquate de l'hyperthermie maligne pouvant suggérer une rechute même si ce n'est pas le cas. 